УДК 612.017.11:616-002-008.953-092

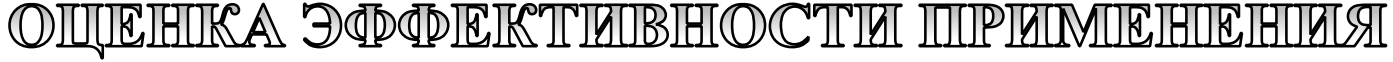

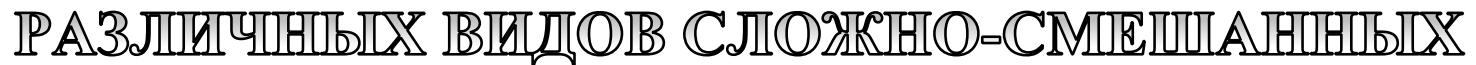

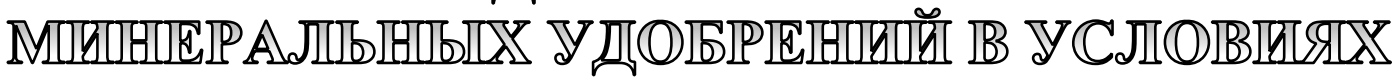

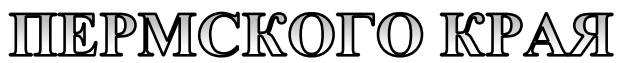

\begin{abstract}
М.Т. Васбиева, Пермский научно-исследовательский институт сельского хозяйства Д.С. Фомин, Пермский научно-исследовательский институт сельского хозяйства В.Р. Ямалтдинова, Пермский научно-исследовательский институт сельского хозяйства Д.Г. Шишков, Пермский научно-исследовательский институт сельского хозяйства Дм.С. Фомин, Пермский научно-исследовательский институт сельского хозяйства Т.В. Новикова, Пермский научно-исследовательский институт сельского хозяйства С.С. Полякова, Пермский научно-исследовательский институт сельского хозяйства
\end{abstract}

\section{Для цитирования:}

Васбиева М.Т., Фомин Д.С., Ямалтдинова В.Р., Шишков Д.Г., Фомин Дм.С., Новикова Т.В., Полякова С.С. Оценка эффективности применения различных видов сложно-смешанных минеральных удобрений в условиях Пермского края // Вестник Пермского федерального исследовательского центра. - 2021. - № 2. - С. 61-70. https://doi.org/10.7242/2658-705X/2021.2.6

Изучена эффрективность применения сложно-смешанных удобрений FertiM $\mathrm{N}_{9} \mathrm{P}_{14} \mathrm{~S}_{10}$, FertiM N ${ }_{10} \mathrm{P}_{10} \mathrm{~K}_{10} \mathrm{~S}_{9}$, FertiM N ${ }_{16} \mathrm{P}_{8} \mathrm{~K}_{8} \mathrm{~S}_{12}$, FertiM $\mathrm{N}_{20} \mathrm{P}_{10} \mathrm{~K}_{10} \mathrm{~S}_{12}$ производства ООО «Терминал-Лысьва» на яровой пшенице сорта Горноуральская и яровом рапсе сорта Подмосковный. Удобрения ООО «Терминал-Лысьва» сравнивали с традиционными удобрениями - аммонийной селитрой и азофоской $\left(\mathrm{N}_{16} \mathrm{P}_{16} \mathrm{~K}_{16}\right)$. Изучено влияние удобрений на урожайность и качество продукции пшеницы.

Максимальная урожайность зерна пшеницы 4,0 т/га получена при внесении FertiM $\mathrm{N}_{20} \mathrm{P}_{10} \mathrm{~K}_{10} \mathrm{~S}_{12}$, что на 0,3 т/га выше, чем при внесении азофоски и на 0,8 т/га выше, чем в контрольном варианте. Применение полного минерального удобрения FertiM $\mathrm{N}_{10} \mathrm{P}_{10} \mathrm{~K}_{10} \mathrm{~S}_{9}$ и FertiM $\mathrm{N}_{20} \mathrm{P}_{10} \mathrm{~K}_{10} \mathrm{~S}_{12}$ обеспечило получение более высокой урожайности культуры (на 0,3-0,5 т/га), чем внесение только азотных (аммонийная селитра) или азотно-фоссфорных удобрений (FertiM $\mathrm{N}_{9} \mathrm{P}_{14} \mathrm{~S}_{10}$ ). При внесении FertiM $\mathrm{N}_{10} \mathrm{P}_{10} \mathrm{~K}_{10} \mathrm{~S}_{9}$ отмечено увеличение содержания сырого белка в зерне с 9,1 до 10,9\%. Урожайность семян ярового рапса при внесении FertiM возросла на 0,2-0,3 т/га. Применение FertiM достоверно повысило содержание в семенах рапса сырого протеина, отмечены тенденции увеличения сырого жира и общего фоссфора. Получены результаты по влиянию сложно-смешанных удобрений FertiM на показатели почвенного плодородия. Внесение сложно-смешанных удобрений FertiM повысило в почве содержание минерального азота в 1,1-1,3 раза. Ухудшения показателей почвеннопоглощающего комплекса не наблюдали.

Ключевые слова: минеральные удобрения, яровая пшеница, яровой рапс, урожайность, качество продукии, дерново-подзолистая почва, агрохимические свойства почвы. 


\section{Введение}

Экологическая парадигма ведения сельского хозяйства предусматривает сбалансированное развитие агроландшафтов, узловым компонентом, которых является почва. Усиленная мобилизация питательных веществ из почвы за счет ее естественных запасов ведет к истощению плодородия и в конечном итоге - к развитию деградационных процессов, а также снижению урожайности и качества продукции сельскохозяйственных культур $[1,2]$. По данным В.Г. Минеева [3], в Российской Федерации ежегодный вынос питательных веществ из почв с урожаем сельскохозяйственных культур в 5 раз превышает возврат их с вносимым объемом удобрений. В Пермском крае наблюдается аналогичная ситуация. В связи с резким сокращением применения удобрений с 2008 года в крае наблюдается ухудшение показателей плодородия почв и снижение урожайности сельскохозяйственных культур [4]. Согласно данным центра агрохимической службы на 01.01.2019 г., 84\% пахотных земель в Пермском крае относятся к категории низкой и очень низкой обеспеченности гумусом, 79\% составляют кислые почвы, 34 и 14\% - с низким содержанием подвижного фосфора и калия. Важным направлением в решении проблемы сохранения и воспроизводства плодородия почвы, улучшения экологической обстановки и формирования высокой продуктивности сельскохозяйственных культур является оптимизация применения удобрений и других агрохимических средств [5-7].

В мире и Уральском регионе ведущее место среди зерновых культур принадлежит яровой пшенице. В зерновом балансе Пермского края она также занимает приоритетное положение, на ее долю в последние пять лет (2015-2019 гг.) приходится $39-43 \%$ от посевных площадей. Востребованность яровой пшеницы объясняется высокой потребительской ценностью и универсальностью использования на пищевые, кормовые и технические цели. Пшеничный хлеб отличается высокими вкусовыми качествами, по питательной ценно- сти и переваримости превосходит хлеб из муки всех других зерновых культур [8].

Возможности для расширения площадей под яровую пшеницу с каждым годом уменьшаются, поэтому увеличение валового сбора зерна может идти за счет повышения урожайности, которая в Пермском крае остается невысокой: за 2015-2019 гг. она варьировалась от 11 до 15 ц/га. Яровая пшеница - культура требовательная к условиям произрастания, прежде всего к наличию в почве легкодоступных питательных веществ, что объясняется коротким периодом вегетации и пониженной усвояющей способностью корневой системы. Использование агрохимических средств является одним из важнейших направлений интенсификации земледелия, снижения уровня зависимости от неблагоприятных климатических условий, повышения качественных показателей сельскохозяйственной продукции, планомерного повышения и сохранения почвенного плодородия. Обоснованное применение удобрений - основа для последовательного повышения производства зерна и один из главных факторов увеличения продуктивности отрасли $[9,10]$.

Рапс - важная масличная культура из семейства капустных, значение которой сильно возросло для человека к концу XX века. Яровой рапс - ценная масличная и кормовая культура. В 2008 г. в Российской Федерации рапс выращивали на 688 тыс. га, в 2018 г. - на 1,05 млн. га. В Пермском крае площади посева рапса за 2013-2019 гг. варьировались от 2,1 до 4,8 тыс. га.

За последние годы (с 2016 по 2019 г.) в Пермском крае районировано 5 сортов и 2 гибрида высокопродуктивных сортов рапса. Потенциальная урожайность составляет около $4 \mathrm{t} / г$. Однако средняя урожайность ярового рапса, несмотря на высокую семенную продуктивность новых сортов, низкая и изменялась за последние годы от 5,5 до 10,2 ц/га. Это объясняется тем, что яровой рапс требует высокого уровня плодородия почв с хорошей обеспеченностью элементами пита- 
ния [11-13]. Одним из приемов адаптивной технологии возделывания рапса, способствующих повышению и стабилизации урожайности, является рациональное использование удобрений. Применение удобрений позволяет рапсу более полно реализовать свой биологический потенциал путем устранения дефицита элементов питания в почве, снижающего продуктивность $[14,15]$.

Цель исследований на 2020 год - изучение эффективности применения сложно-смешанных удобрений производства ООО «Терминал-Лысьва» на яровой пшенице сорта Горноуральская и яровом рапсе сорта Подмосковный.

\section{Методика и условия проведения исследований}

В 2020 году испытание сложно-смешанных удобрений проводили на опытном поле Пермского НИИСХ - филиала ПФИЦ УрО РАН. Было заложено 2 полевых опыта в соответствии с общепринятой методикой Б.А. Доспехова [16]. Изучали 4 вида сложно-смешанных удобрений производства ООО «Терминал-Лысьва»: FertiM $\mathrm{N}_{9} \mathrm{P}_{14} \mathrm{~S}_{10}$, FertiM $\mathrm{N}_{10} \mathrm{P}_{10} \mathrm{~K}_{10} \mathrm{~S}_{9}$, FertiM $\mathrm{N}_{16} \mathrm{P}_{8} \mathrm{~K}_{8} \mathrm{~S}_{12}$, FertiM $\mathrm{N}_{20} \mathrm{P}_{10} \mathrm{~K}_{10} \mathrm{~S}_{12}$. Проводили сравнение изучаемых удобрений с традиционными видами удобрений: аммонийной селитрой $\left(\mathrm{N}_{34,4}\right)$ и азофоской $\left(\mathrm{N}_{16} \mathrm{P}_{16} \mathrm{~K}_{16}\right)$. Схема опыта включала 7 вариантов в 3-кратной повторности.

\section{Схема опыта:}

1. Контроль (без удобрений)

2. Аммиачная селитра $\mathrm{N}_{34,4}$

3. Азофоска $\mathrm{N}_{16} \mathrm{P}_{16} \mathrm{~K}_{16}$

4. FertiM N ${ }_{9} \mathrm{P}_{14} \mathrm{~S}_{10}$

5. FertiM N ${ }_{10} \mathrm{P}_{10} \mathrm{~K}_{10} \mathrm{~S}_{9}$

6. FertiM N ${ }_{16} \mathrm{P}_{8} \mathrm{~K}_{8} \mathrm{~S}_{12}$

7. FertiM N ${ }_{20} \mathrm{P}_{10} \mathrm{~K}_{10} \mathrm{~S}_{12}$

Onblm 1. Изучение эффективности применения сложно-смешанных удобрений производства ООО «Терминал-Лысьва» на яровой пшенице.

Применение удобрений рассчитывали по азоту. Доза среднерекомендуемая -
$\mathrm{N}_{30}$. Минеральные удобрения вносили вручную, под предпосевную культивацию. Размещение делянок систематическое, в 3 яруса, общая площадь делянки $60 \mathrm{~m}^{2}$, учетная - $20 \mathrm{~m}^{2}$. Объектом исследования была пшеница сорта Горноуральская. Норма высева пшеницы - 7 млн. всхожих зерен на 1 га. Посев яровой пшеницы проведен 11 мая. Полные всходы были отмечены - 25 мая. Учет урожайности проведен 4 сентября. Предшественник - овес. Обработка почвы - общепринятая для Пермского края. Проведено опрыскивание посевов гербицидами Гербикс 0,6 л/га +Террамет 5 г/га.

Почва участка дерново-подзолистая, тяжелосуглинистая среднегумусированная (2,5-3,0 \%), с сильнокислой реакцией среды $\left(\mathrm{pH}_{\mathrm{KCl}} 4,5\right)$ и очень высоким содержанием фосфора - 256 мг/кг.

Onblm 2. Изучение эффективности применения сложно-смешанных удобрений производства ООО «Терминал-Лысьва» на яровом рапсе.

Применение удобрений рассчитывали по азоту. Доза среднерекомендуемая - $\mathrm{N}_{90}$. Минеральные удобрения вносили вручную, под предпосевную культивацию. Размещение делянок систематическое, общая площадь делянки $42 \mathrm{~m}^{2}$, учетная - $30 \mathrm{~m}^{2}$. Объектом исследования был яровой рапс сорта Подмосковный. Норма высева 0,5 млн всхожих семян на 1 га. Посев рапса проведен 10 мая. Полные всходы были отмечены 26 мая. Учет урожайности проведен 1 октября. Предшественник - овес. Обработка почвы общепринятая для Пермского края. Проведено опрыскивание посевов гербицидами Хакер, Миура, инсектицидом Альфа-Ципи.

Почва участка дерново-подзолистая, тяжелосуглинистая, слабогумусированная $(2,1 \%)$, со слабокислой реакцией среды $\left(\mathrm{pH}_{\mathrm{KCl}} 5,4\right)$ и высоким содержанием фосфора - $180 \mathrm{мг/кг.}$

Для определения влияния удобрений на свойства дерново-подзолистой почвы осенью после уборки культуры проводили отбор почвенных образцов в слое 0-20 см [17]. Агрохимические свойства 
почвы в образцах определяли с соответствии с ГОСТами и методиками ЦИНАО. Растительные образцы для определения структуры урожайности пшеницы были отобраны перед уборкой культуры. Структуру урожайности определяли по методике, описанной В.М. Макаровой [18]. Содержание азота и фосфора в зерне и соломе пшеницы определяли в воздушно-сухих размолотых образцах: общего азота - по методу Кьельдаля, общего фосфора - фотоколориметрически после озоления [17].

Отбор растительных образцов рапса проводили одновременно с уборкой культуры для определения биохимического состава и показателей качества семян (зоотехнический анализ).

Статистическую обработку результатов опыта проводили методами дисперсионного и корреляционно-регрессионного анализов [15] с использованием пакета программ Microsoft Excel.

Метеорологические условия вегетаичионного периода 2020 года. Средняя месячная температура воздуха в апреле составила $+4,3^{\circ} \mathrm{C}$, что $0,7^{\circ} \mathrm{C}$ выше средних многолетних значений. За месяц выпало 42 мм осадков - $117 \%$ от нормы. Сход устойчивого снежного покрова наблюдали в сроки, близкие к средним многолетним датам, - во второй декаде апреля. Май характеризовался неустойчивой погодой. В первой декаде наблюдали превышение среднемноголетней температуры на $6^{\circ} \mathrm{C}$. Наиболее теплые дни были 5-11 мая. Максимальный прогрев воздуха в этот период достигал $28,2{ }^{\circ} \mathrm{C}$ (установлен новый абсолютный максимум, прежний составлял $27,7^{\circ} \mathrm{C}$ и был отмечен в 1962 г.). Вслед за ослабевающей жарой в регион пришло похолодание, во второй декаде отмечено понижение температуры воздуха до $-1 \ldots 0^{\circ} \mathrm{C}$. Средняя температура воздуха за месяц составила $+13^{\circ} \mathrm{C}$, что на $2,3^{\circ} \mathrm{C}$ выше климатической нормы. Осадков за месяц выпало чуть больше обычного 75 мм - 127\% от нормы, большая часть пришлась на третью декаду мая - 65 мм.
Лето 2020 г. в целом характеризовалось температурой воздуха, близкой к норме, на фоне умеренного дефицита осадков. Средняя температура летнего сезона оказалась выше, чем в 2017-2019 гг. В период с 6 по 11 июня отмечалась аномально жаркая погода со среднесуточной температурой $19-24^{\circ} \mathrm{C}$, что на $4-8^{\circ} \mathrm{C}$ выше нормы. Вторая и третья декады были холодными. Средняя месячная температура воздуха в июне составила $14,1^{\circ} \mathrm{C}$, что на $2,5^{\circ} \mathrm{C}$ ниже средних многолетних значений. За месяц выпало 89 мм осадков, это чуть больше нормы (110\%).

Июль характеризовался устойчивой погодой. Средняя месячная температура воздуха была $+21,2^{\circ} \mathrm{C}$, выше климатической нормы на $3,1^{\circ}$. Сумма осадков за месяц составила 36 мм - в два раза меньше нормы. Формирование урожая основных сельскохозяйственных культур проходило в условиях повышенного уровня тепла и пониженной влагообеспеченности. В августе погода носила неустойчивый характер. Если температурный фон первой декады был в пределах нормы, то во второй декаде он оказалась на $3,5^{\circ}$ ниже нормы, третья декада, в противоположность второй, оказалась теплее обычного на $3,1^{\circ} \mathrm{C}$. В целом средняя месячная температура воздуха составила $+15,4^{\circ} \mathrm{C}$, что в пределах нормы. Наблюдался недобор осадков - 66 мм, что составило $87 \%$ от нормы. Наиболее дождливой была вторая декада.

Сентябрь характеризовался температурой воздуха и количеством выпавших осадков близким к норме. Средняя месячная температура воздуха составила $+10,2^{\circ} \mathrm{C}$, осадков выпало 42 мм. Переход среднесуточной температуры воздуха через $10^{\circ} \mathrm{C}$ в сторону похолодания произошел 15 сентября (около нормы). Закончился период активной вегетации. Условия для уборки сельскохозяйственных культур были благоприятные.

\section{Результаты исследований}

Внесение минеральных удобрений производства ООО «Терминал-Лысьва» в климатических условиях вегетационного пе- 
риода 2020 года обеспечило достоверное повышение урожайности зерна яровой пшеницы на $0,3-0,8$ т/га $\left(\mathrm{HCP}_{05}=0,3 \mathrm{т} / \mathrm{ra}\right)$ (рис. 1). Максимальная урожайность культуры в опыте 4,0 т/га получена при внесении FertiM $\mathrm{N}_{20} \mathrm{P}_{10} \mathrm{~K}_{10} \mathrm{~S}_{12}$, что на 0,3 т/га выше, чем при внесении стандартного удобрения азофоски. Применение полного минерального удобрения FertiM при соотношении элементов питания NPKS 10:10:10:9 и 20:10:10:12 обеспечило получение более высокой урожайности культуры (на 0,3-0,5 т/га), чем внесение только азотных (аммонийная селитра) или азотно-фосфорных удобрений (FertiM N $\left.{ }_{9} \mathrm{P}_{14} \mathrm{~S}_{10}\right)$.
Биометрический анализ урожайности показал, что при внесении FertiM $\mathrm{N}_{20} \mathrm{P}_{10} \mathrm{~K}_{10} \mathrm{~S}_{12}$ прибавка урожая получена в первую очередь за счет увеличения числа зерен в колосе с 21 до 26 и продуктивности колоса с 0,71 до 0,90 г (табл. 1). Коэффициенты корреляции между данными показателями и урожайностью культуры высокие: $\mathrm{r}=0,8-0,9$.

Внесение минеральных удобрений производства ООО «Терминал-Лысьва» в климатических условиях вегетационного периода 2020 года обеспечило достоверное повышение урожайности семян ярового рапса на 0,23-0,32 т/га

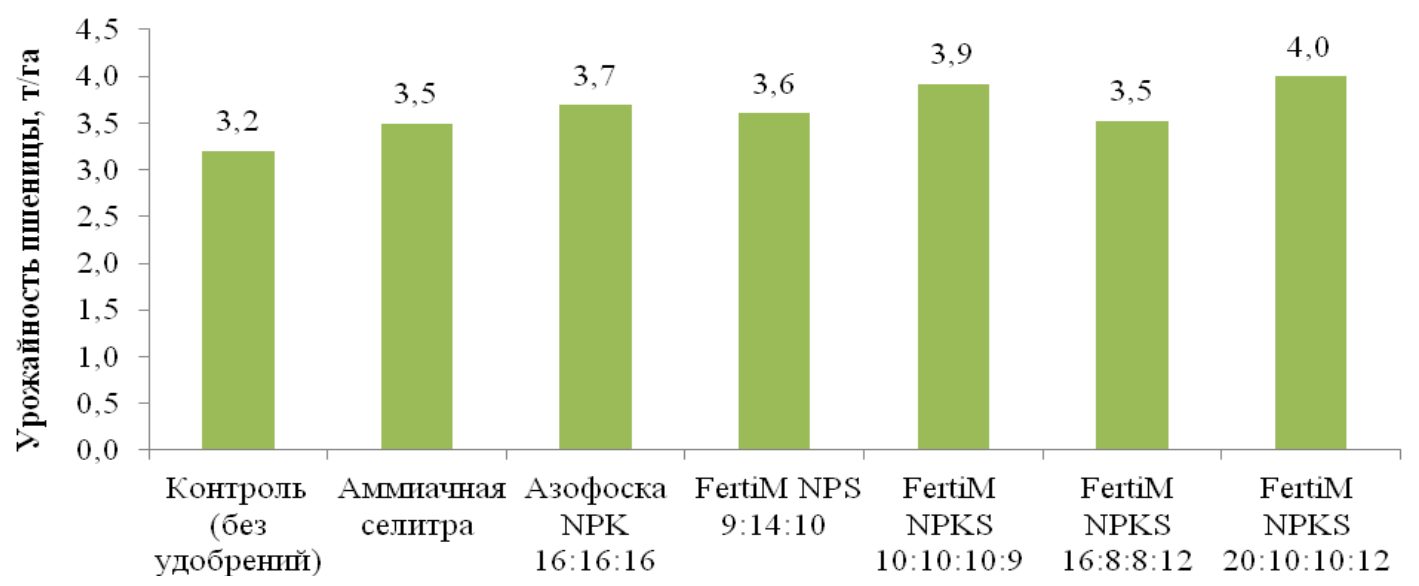

Рис. 1. Влияние минеральных удобрений на урожайность яровой пшениць сорта Горноуральская

Структура урожайности яровой пшеницы сорта Горноуральская

Таблица 1

\begin{tabular}{|c|c|c|c|c|c|c|c|}
\hline Варианты & $\begin{array}{c}\text { Доза } \\
\text { внесения, } \\
\text { кг д.в. на га }\end{array}$ & \begin{tabular}{|c|} 
Число \\
продуктивных \\
стеблей, \\
шт \\
\end{tabular} & $\begin{array}{c}\text { Длина } \\
\text { колоса, } \\
\text { см }\end{array}$ & \begin{tabular}{|c|} 
Число \\
зерен \\
в колосе, \\
шт \\
\end{tabular} & $\begin{array}{c}\text { Мacca } \\
1000 \text { зерен, } \\
\text { г }\end{array}$ & \begin{tabular}{|l} 
Проду- \\
ктивность \\
колоса, г
\end{tabular} & $\begin{array}{c}\text { Биологическая } \\
\text { урожайность, } \\
\text { т/га }\end{array}$ \\
\hline $\begin{array}{l}\text { Контроль } \\
\text { (без удобрений) }\end{array}$ & - & 602 & 6,0 & 21 & 33,4 & 0,71 & 3,8 \\
\hline $\begin{array}{l}\text { Аммиачная } \\
\text { селитра } \\
\mathrm{N}_{34,4} \\
\end{array}$ & N30 & 574 & 6,3 & 24 & 33,2 & 0,80 & 4,5 \\
\hline $\begin{array}{l}\text { Азофосска } \\
\mathrm{N}_{16} \mathrm{P}_{16} \mathrm{~K}_{16} \\
\end{array}$ & N30P30K30 & 657 & 6,2 & 22 & 32,4 & 0,75 & 4,4 \\
\hline $\begin{array}{l}\text { FertiM } \\
\mathrm{N}_{9} \mathrm{P}_{14} \mathrm{~S}_{10} \\
\end{array}$ & N30P47S33 & 604 & 6,6 & 23 & 33,3 & 0,76 & 4,5 \\
\hline $\begin{array}{l}\text { FertiM } \\
\mathrm{N}_{10} \mathrm{P}_{10} \mathrm{~K}_{10} \mathrm{~S}_{9}\end{array}$ & N30P30K30S27 & 653 & 6,7 & 24 & 32,3 & 0,74 & 4,9 \\
\hline $\begin{array}{l}\text { FertiM } \\
\mathrm{N}_{16} \mathrm{P}_{8} \mathrm{~K}_{8} \mathrm{~S}_{12}\end{array}$ & N30P15K15S22 & 644 & 7,1 & 24 & 33,7 & 0,81 & 5,0 \\
\hline $\begin{array}{l}\text { FertiM } \\
\mathrm{N}_{20} \mathrm{P}_{10} \mathrm{~K}_{10} \mathrm{~S}_{12}\end{array}$ & N30P15K15S18 & 654 & 7,3 & 26 & 33,7 & 0,90 & 5,4 \\
\hline $\mathrm{HCP}_{05}$ & - & $\mathrm{F} \phi<\mathrm{FT}$ & 0,8 & 5 & $\mathrm{~F} \phi<\mathrm{FT}$ & 0,18 & 0,5 \\
\hline
\end{tabular}


$\left(\mathrm{HCP}_{05}=0,18 \mathrm{т} / г а\right)$ (рис. 2). Прибавка урожайности от удобрений FertiM получена на уровне азофоски и аммонийной селитры. Рапс - влаголюбивая культура, поэтому его урожайность в сухие годы бывает низкой. Основной причиной резкого падения урожайности в засуху становится дефицит осадков в июле, который совпадает с периодом начало цветения - созревания семян культуры. Сумма осадков в июле составила 36 мм - в два раза меньше нормы. Влияние неблагоприятных условий влагообеспеченности в период формирования семян и их налива привело к снижению урожайности культуры.

Изучено влияние применения сложносмешанных удобрений производства ООО «Терминал-Лысьва» на агрохимические свойства дерново-подзолистой тяжелосуглинистой почвы (табл. 2,3). Внесе-

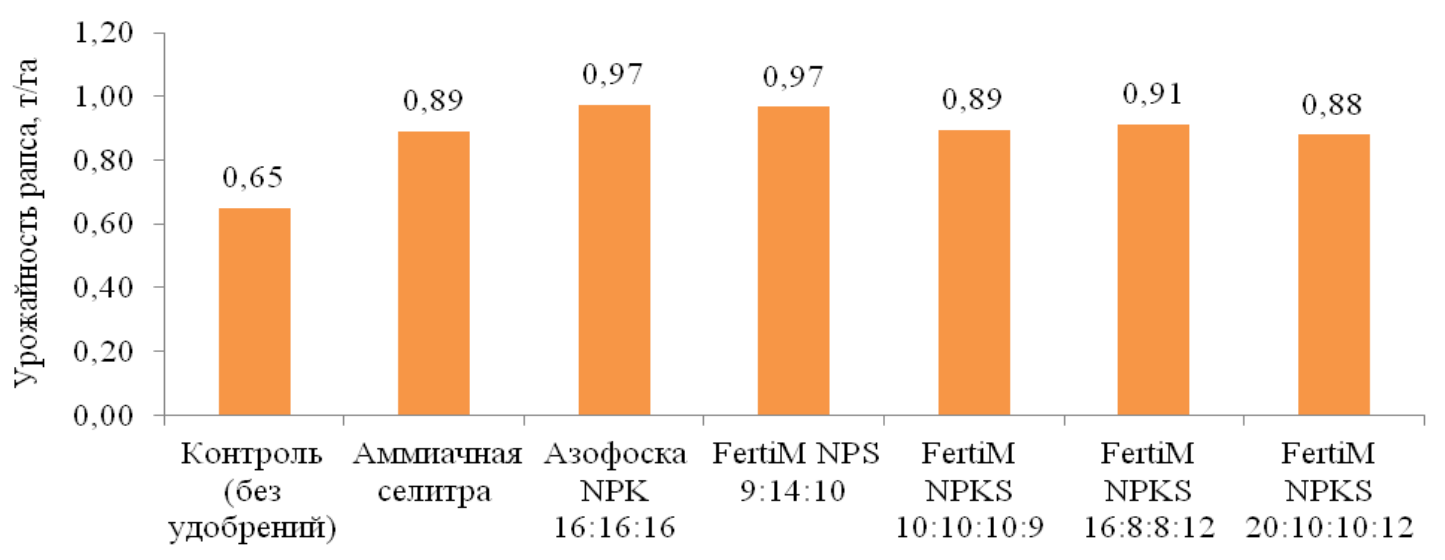

Рис. 2. Влияние минеральньх удобрений на урожайность ярового рапса сорта Подмосковный

\section{Влияние удобрений на агрохимические показатели плодородия дерново-подзолистой почвы (яровая пшеница)}

Таблица 2

\begin{tabular}{|c|c|c|c|c|c|c|c|c|c|c|}
\hline \multirow{2}{*}{ Варианты } & \multirow{2}{*}{$\mathrm{pH} \mathrm{KCL}$} & $\mathrm{Hr}$ & S & $\mathrm{Ca}$ & $\mathrm{Mg}$ & \multirow{2}{*}{$\mathrm{V}, \%$} & \multicolumn{4}{|c|}{ 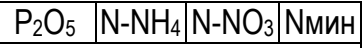 } \\
\hline & & \multicolumn{4}{|c|}{ смоль(ЭКв)/кг } & & \multicolumn{4}{|c|}{$\mathrm{Mr} / \mathrm{kr}$} \\
\hline Контроль & 4,5 & 4,1 & 24,2 & 22,6 & 3,1 & 85 & 243 & 26,9 & 5,7 & 32,6 \\
\hline Аммиачная селитра $\mathrm{N}_{34,4}$ & 4,5 & 4,4 & 23,6 & 21,1 & 3,8 & 84 & 261 & 31,3 & 6,2 & 37,4 \\
\hline Азофооска $\mathrm{N}_{16} \mathrm{P}_{16} \mathrm{~K}_{16}$ & 4,6 & 4,3 & 24,0 & 21,0 & 4,1 & 85 & 220 & 42,7 & 6,2 & 48,9 \\
\hline FertiM $\mathrm{N}_{9} \mathrm{P}_{14} \mathrm{~S}_{10}$ & 4,6 & 4,4 & 24,3 & 20,7 & 3,0 & 85 & 198 & 35,3 & 6,7 & 42,0 \\
\hline FertiM $\mathrm{N}_{10} \mathrm{P}_{10} \mathrm{~K}_{10} \mathrm{~S}_{9}$ & 4,5 & 4,4 & 23,8 & 20,9 & 3,2 & 83 & 211 & 36,8 & 7,0 & 43,7 \\
\hline FertiM $N_{16} \mathrm{P}_{8} \mathrm{~K}_{8} \mathrm{~S}_{12}$ & 4,4 & 4,3 & 23,3 & 21,6 & 2,8 & 85 & 266 & 25,5 & 7,9 & 33,3 \\
\hline FertiM N & 4,5 & 4,4 & 23,5 & 21,9 & 3,1 & 84 & 270 & 28,8 & 8,1 & 36,9 \\
\hline $\mathrm{x} \pm \mathrm{t}_{\mathrm{p}} \mathrm{m}^{\star *} / \mathrm{HCP}_{05}$ & $\mathrm{~F} \phi<\mathrm{F}$ & 0,2 & $\mathrm{~F} \phi<\mathrm{FT}_{\mathrm{T}}$ & 1,1 & $\mathrm{~F} \phi<\mathrm{FT}_{\mathrm{T}}$ & $\mathrm{F} \phi<\mathrm{FT}_{\mathrm{T}}$ & $\mathrm{F}_{\mathrm{p}}<\mathrm{FT}_{\mathrm{T}}$ & 5,2 & 0,7 & 5,6 \\
\hline
\end{tabular}

Влияние удобрений на агрохимические показатели плодородия почвы (яровой рапс)

Табличза 3

\begin{tabular}{|c|c|c|c|c|c|c|c|c|c|c|}
\hline \multirow{2}{*}{ Варианты } & \multirow{2}{*}{$\mathrm{pH} \mathrm{KCL}_{\mathrm{L}}$} & $\mathrm{Hr}$ & $S$ & $\mathrm{Ca}$ & $\mathrm{Mg}$ & \multirow{2}{*}{$\mathrm{V}, \%$} & $\mathrm{P}_{2} \mathrm{O}_{5}$ & \multicolumn{2}{|c|}{\begin{tabular}{|l|l|}
$\mathrm{N}-\mathrm{NH}_{4}$ & $\mathrm{~N}-\mathrm{NO}_{3}$ \\
\end{tabular}} & Nмин \\
\hline & & \multicolumn{4}{|c|}{ смоль(ЭКв)/кг } & & \multicolumn{4}{|c|}{$\mathrm{M} \Gamma / \mathrm{K} \Gamma$} \\
\hline Контроль & 5,0 & 2,0 & 18,5 & 14,3 & 3,3 & 90 & 260 & 12,9 & 7,3 & 20,2 \\
\hline Аммиачная селитра $\mathrm{N}_{34,4}$ & 5,0 & 2,1 & 18,6 & 14,4 & 2,9 & 90 & 240 & 10,8 & 5,0 & 15,7 \\
\hline Азофоска $\mathrm{N}_{16} \mathrm{P}_{16} \mathrm{~K}_{16}$ & 5,0 & 2,1 & 18,9 & 14,3 & 2,9 & 90 & 230 & 13,1 & 6,4 & 19,5 \\
\hline FertiM $\mathrm{N}_{9} \mathrm{P}_{14} \mathrm{~S}_{10}$ & 5,0 & 2,2 & 20,2 & 14,3 & 4,0 & 90 & 265 & 10,1 & 6,9 & 17,0 \\
\hline FertiM $\mathrm{N}_{10} \mathrm{P}_{10} \mathrm{~K}_{10} \mathrm{~S}_{9}$ & 5,0 & 2,2 & 20,2 & 15,5 & 3,5 & 90 & 275 & 10,8 & 6,7 & 17,5 \\
\hline FertiM N ${ }_{16} \mathrm{P}_{8} \mathrm{~K}_{8} \mathrm{~S}_{12}$ & 5,0 & 2,2 & 19,0 & 14,4 & 2,9 & 90 & 245 & 11,6 & 8,3 & 19,9 \\
\hline FertiM N ${ }_{20} \mathrm{P}_{10} \mathrm{~K}_{10} \mathrm{~S}_{12}$ & 5,1 & 2,1 & 20,6 & 14,4 & 4,0 & 91 & 215 & 9,0 & 8,2 & 17,2 \\
\hline $\mathrm{x} \pm \mathrm{t}_{\mathrm{p}} \mathrm{m}^{* *} / \mathrm{HCP}_{05}$ & $\mathrm{~F} \phi<<\mathrm{FT}$ & $\mathrm{F} \phi<\mathrm{F}$ & $\mathrm{F} \phi p<\mathrm{FT}$ & $\mathrm{F} \phi<<\mathrm{FT}_{\mathrm{T}}$ & $=\mathrm{p}<\mathrm{FT}$ & - & $\mathrm{F} \phi<<\mathrm{FT}$ & 2,0 & 1,3 & $\mathrm{~F} \phi<<\mathrm{FT}$ \\
\hline
\end{tabular}


ние сложно-смешанных удобрений достоверно повысило в почве содержание минерального азота (сумма аммонийного и нитратного азота) в 1,1-1,3 раза. Применение удобрений не оказало существенного влияния на содержание в почве подвижного фосфора и показатели почвенно-поглощающего комплекса.

Наряду с урожайностью культур большое практическое значение имеет изучение химического состава растениеводческой продукции. Применение FertiM $\mathrm{N}_{10} \mathrm{P}_{10} \mathrm{~K}_{10} \mathrm{~S}_{9}$ под яровую пшеницу достоверно повысило в зерне содержание азота с 1,59 (контроль) до $1,92 \%$ и соответственно сырого белка с 9,1 до 10,9\% (табл. 4). Полученные результаты Таблицуа 4

Влияние удобрений на элементный состав зерна и соломы яровой пшеницы, \% сухого вещества

\begin{tabular}{|c|c|c|c|c|}
\hline \multirow{2}{*}{ Варианты } & \multicolumn{2}{|c|}{ Зерно } & \multicolumn{2}{|c|}{ Солома } \\
\hline & $\mathrm{N}$ & $P$ & $\mathrm{~N}$ & $P$ \\
\hline Контроль & 1,59 & 1,90 & 0,27 & 0,22 \\
\hline Аммиачная селитра $\mathrm{N}_{34,4}$ & 1,66 & 1,99 & 0,26 & 0,18 \\
\hline Азофроска $\mathrm{N}_{16} \mathrm{P}_{16} \mathrm{~K}_{16}$ & 1,70 & 1,88 & 0,23 & 0,18 \\
\hline FertiM $\mathrm{N}_{9} \mathrm{P}_{14} \mathrm{~S}_{10}$ & 1,59 & 1,84 & 0,34 & 0,22 \\
\hline FertiM $\mathrm{N}_{10} \mathrm{P}_{10} \mathrm{~K}_{10} \mathrm{~S}_{9}$ & 1,92 & 1,85 & 0,46 & 0,23 \\
\hline FertiM N ${ }_{16} \mathrm{P}_{8} \mathrm{~K}_{8} \mathrm{~S}_{12}$ & 1,59 & 1,91 & 0,18 & 0,19 \\
\hline FertiM $\mathrm{N}_{20} \mathrm{P}_{10} \mathrm{~K}_{10} \mathrm{~S}_{12}$ & 1,75 & 1,89 & 0,32 & 0,20 \\
\hline $\mathrm{HCP}_{05}$ & 0,14 & $\mathrm{~F} \phi<<\mathrm{FT}_{\mathrm{T}}$ & $F \phi<F$ & $\mathrm{~F} \phi<\mathrm{FT}$ \\
\hline
\end{tabular}

возможно связаны с более оптимальным соотношением элементов питания в данном виде удобрения. Применение изучаемых удобрений не оказало существенного влияния на содержание азота в соломе, содержание фосфора в зерне и соломе яровой пшеницы. Все отклонения находились в пределах ошибки опыта.

Применение сложно-смешанных удобрений FertiM достоверно повысило содержание в семенах рапса сырого протеина с 23,3 (контроль) до 24,3-24,8\% (табл. 5).

Также отмечены тенденции увеличения сырого жира и общего фосфора. При внесении аммонийной селитры и азофоски содержание сырого протеина и сырого жира сохранилось на уровне контрольного варианта. Полученные результаты по применению FertiM, возможно, связаны с наличием в данных удобрениях серы. При их внесении в почву поступило, в зависимости от марки удобрения, от 54 до 99 кг серы.

\section{Выводы}

Применение сложно-смешанных удобрений ООО «Терминал-Лысьва» FertiM $\mathrm{N}_{9} \mathrm{P}_{14} \mathrm{~S}_{10}, \quad$ FertiM $\quad \mathrm{N}_{10} \mathrm{P}_{10} \mathrm{~K}_{10} \mathrm{~S}_{9}, \quad$ FertiM $\mathrm{N}_{16} \mathrm{P}_{8} \mathrm{~K}_{8} \mathrm{~S}_{12}$, FertiM N ${ }_{20} \mathrm{P}_{10} \mathrm{~K}_{10} \mathrm{~S}_{12}$ в климатических условиях вегетационного периода 2020 года обеспечило достоверное повышение урожайности зерна яровой пшеницы на 0,3-0,8 т/га. Максимальная урожай-

Таблийа 5

Влияние удобрений на биохимический состав семян ярового рапса, \% на абсолютно сухое вещество

\begin{tabular}{|c|c|c|c|c|c|c|}
\hline Варианты & $\begin{array}{c}\text { Сырой } \\
\text { протеин }\end{array}$ & Сырой жир & Сырая клетчатка & Сырая зола & Общий фосффор & $\begin{array}{l}\text { Общий } \\
\text { калий }\end{array}$ \\
\hline Контроль & 23,3 & 25,6 & 9,3 & 4,2 & 1,77 & 0,87 \\
\hline \begin{tabular}{|l|} 
Аммиачная \\
селитра N 34,4
\end{tabular} & 23,6 & 25,4 & 9,2 & 4,2 & 1,84 & 0,93 \\
\hline $\begin{array}{l}\text { Aзосроска } \\
\mathrm{N}_{16} \mathrm{P}_{16} \mathrm{~K}_{16} \\
\end{array}$ & 23,8 & 25,5 & 9,2 & 4,2 & 1,83 & 0,93 \\
\hline \begin{tabular}{|l} 
FertiM \\
$\mathrm{N}_{9} \mathrm{P}_{14} \mathrm{~S}_{10}$ \\
\end{tabular} & 24,3 & 25,4 & 9,4 & 4,2 & 1,84 & 0,88 \\
\hline $\begin{array}{l}\text { FertiM } \\
\mathrm{N}_{10} \mathrm{P}_{10} \mathrm{~K}_{10} \mathrm{~S}_{9}\end{array}$ & 24,8 & 26,0 & 9,4 & 4,3 & 1,85 & 0,99 \\
\hline $\begin{array}{l}\text { FertiM } \\
\mathrm{N}_{16} \mathrm{P}_{8} \mathrm{~K}_{8} \mathrm{~S}_{12}\end{array}$ & 24,8 & 26,1 & 9,2 & 4,3 & 1,87 & 0,91 \\
\hline $\begin{array}{l}\text { FertiM } \\
\mathrm{N}_{20} \mathrm{P}_{10} \mathrm{~K}_{10} \mathrm{~S}_{12}\end{array}$ & 24,6 & 26,1 & 9,3 & 4,2 & 1,87 & 0,90 \\
\hline $\mathrm{HCP}_{05}$ & 0,9 & $\mathrm{~F} \phi<\mathrm{FT}_{\mathrm{T}}$ & $\mathrm{F} \phi<\mathrm{FT}_{\mathrm{T}}$ & $\mathrm{F} \phi<\mathrm{FT}$ & $\mathrm{F} \phi<\mathrm{FT}$ & F $\phi<F T$ \\
\hline
\end{tabular}


ность культуры $(4,0$ т/га) получена при внесении FertiM $\mathrm{N}_{20} \mathrm{P}_{10} \mathrm{~K}_{10} \mathrm{~S}_{12}$, что на 0,3 т/га выше, чем при внесении стандартного удобрения азофоски. Применение полного минерального удобрения FertiM при соотношении элементов питания NPKS 10:10:10:9 и 20:10:10:12 обеспечило получение более высокой урожайности культуры (на 0,3-0,5 т/га), чем внесение только азотных (аммонийная селитра) или азотно-фосфорных удобрений (FertiM $\left.\mathrm{N}_{9} \mathrm{P}_{14} \mathrm{~S}_{10}\right)$. Прибавки урожая пшеницы получены за счет увеличения числа зерен в колосе и продуктивности колоса. Применение минеральных удобрений (FertiM, азофоски, аммонийной селитры) не оказало существенного влияния на содержание в зерне и соломе яровой пшеницы основных элементов питания. Исключение составил вариант с внесением FertiM $\mathrm{N}_{10} \mathrm{P}_{10} \mathrm{~K}_{10} \mathrm{~S}_{9}$, здесь отмечено увеличение содержания азота с 1,59 (контроль) до 1,92\% и соответственно, сырого белка - с 9,1 до 10,9\%.
Урожайность семян ярового рапса при внесении FertiM повысилась на $0,2-0,3$ т/га. Прибавка урожайности от удобрений FertiM получена на уровне азофоски и аммонийной селитры. Применение FertiM достоверно повысило содержание в семенах рапса сырого протеина с 23,3 до 24,3-24,8\%. Также отмечены тенденции увеличения сырого жира и общего фосфора. При внесении аммонийной селитры и азофоски содержание сырого протеина и сырого жира сохранилось на уровне контрольного варианта. Полученные результаты, возможно, связаны с содержанием в FertiM серы.

Внесение сложно-смешанных удобрений FertiM повысило в почве содержание минерального азота (сумма аммонийного и нитратного азота) в 1,1-1,3 раза. Ухудшения показателей почвенно-поглощающего комплекса (кислотности почвы, суммы обменных оснований и др.) не наблюдали.

\section{Библиографический список}

1. Милащенко Н.З., Соколов О.А., Брайсон Т., Черников В.А. Устойчивое развитие агроландшафтов. Пущино: ОНТИ ПНЦ РАН, 2000. - 316 с.

2. Кирюшин В.И. Теория адаптивно-ландшафтного земледелия и проектирование агроландшафтов. М.: «Колос», 2011. С. 65-85.

3. Минеев В.Г. Актуальные проблемы агрохимии в современном земледелии / Состояние и перспективы агрохимических исследований в географической сети опытов с удобрениями. - М.; 2010. С. 7-10.

4. Кайгородов Н.T. 50 лет агрохимической службе Пермского края. - Пермь, 2014. 52 с.

5. Завьялова Н.Е. Органическое вещество дерново-подзолистых почв Предуралья / Н.Е.Завьялова. Пермь: «От и ДО», 2014. - 328 с.

6. Сычёв В.Г., Шафран С.А., Виноградова С.Б. Плодородие почвы России и пути его регулирования // Агрохимия. - 2020. - № 6. -С. 3-13.

7. Казак А.А., Логинов Ю.П. Влияние уровня минерального питания на урожайность и качество зерна сортов пшеницы в северной лесостепи Тюменской области // Известия Оренбургского государственного аграрного университета. - 2019. - № 3. - С. 41-46.

8. Шаболкина Е.Н., Чичкин А.П. Влияние удобрений на продуктивность и содержание белка в зерне яровой пшеницы в условиях Среднего Поволжья // Известия Оренбургского государственного аграрного университета. - 2011. - № 2 (30-1). - С. 35-39.

9. Казак А.А., Логинов Ю.П., Ерёмин Д.И. Влияние минеральных удобрений на урожайность и качество семян сортов пшеницы в северной лесостепи Тюменской области // Аграрная наука Евро-Северо-Востока. - 2019. - № 3. - С. 219-229.

10. Волынкина О.В. Фосфорное удобрение усиливает действие азота на урожай и качество пшеницы // Проблемы агрохимии и экологии. - 2019. - № 1. - С. 21-25.

11. Лупова Е.И., Виноградов Д.В. Влияние гуминового удобрения и доз минеральных удобрений на продуктивность ярового рапса // Вестник аграрной науки. - 2020. - №3 (84). - С. 31-37.

12. Сулейманов И.Р., Гилязов М.Ю. Действие серосодержащих удобрений на урожайность ярового рапса и потребление макроэлементов растениями в условиях серой лесной почвы // Агрохимический вестник. - 2010. - № 4. - С. 20-22.

13. Карома А.Н., Нурльгаянов Р.Б. Урожайность семян ярового рапса при различных дозах минеральных удобрений в условиях подтаежной зоны Кемеровской области // Плодородие. - 2014. - № 5. - С. $23-25$. 
14. Наздрачёв Я.П. Применение минеральных удобрений при возделывании ярового рапса на маслосемена на черноземе южном // Сибирский вестник сельскохозяйственной науки. - 2014. - № 6. - С. 110-117.

15. Полтораднев М.С. Гребенникова Т.В. Эффективность азотного серосодержащего удобрения NS 30:7 при возделывании ярового рапса в Северной Европе // Земледелие. - 2015. - № 8. - С. 37-38.

16. Доспехов Б.А. Методика полевого опыта (с основами статистической обработки результатов исследований). - М.: Агропромиздат, 1985. - 351 с.

17. Практикум по агрохимии: учеб. пособие / под ред. В.Г. Минеева. - М.: МГУ, 2001. - 639 с.

18. Макарова В.М. Структура урожайности зерновых культур и ее регулирование. - Пермь, $1995 .-144 \mathrm{c}$.

\title{
ESTIMATION OF THE EFFICIENCY OF APPLICATION OF COMPLICATED-MIXED MINERAL FERTILIZERS IN THE CONDITIONS OF PERM REGION
}

\author{
M.T. Vasbieva, D.S. Fomin, V.R. Yamaltdinova, D.G. Shishkov, \\ Dm.S. Fomin, T.V. Novikova, S.S. Polyakova \\ Perm Scientific Research Institute of Agriculture
}

\begin{abstract}
For citation:
Vasbieva M.T., Fomin D.S., Yamaltdinova V.R., Shishkov D.G., Fomin Dm.S., Novikova T.V., Polyakova S.S. Estimation of the efficiency of application of complicated-mixed mineral fertilizers in the conditions of Perm region // Perm Federal Research Center Journal. - 2021 . № 2. - P. 61-70. https://doi.org/10.7242/2658-705X/2021.2.6
\end{abstract}

The efficiency of using complex-mixed fertilizers FertiM N9P14S10, FertiM N10P10K10S9, FertiM N16P8K8S12, FertiM N20P10K10S12 produced by Terminal-Lysva LLC on spring wheat of the Gornouralskaya variety and spring rape of the Podmoskovny variety has been studied. Fertilizers of Terminal-Lysva LLC were compared with traditional ammonium nitrate and complex Azophos (N16P16K16) fertilizers. The influence of fertilizers on the yield and quality of wheat products has been studied. The maximum wheat grain yield of 4,0 t/ha was obtained with the introduction of FertiM N20P10K10S12, which is 0,3 t/ha higher than with the application of complex fertilizer N16P16K16 and 0,8 t/ha higher than in the control variant. The use of the complete mineral fertilizer FertiM N10P10K10S9 and FertiM N20P10K10S12 ensured a higher crop yield (by 0,3-0,5 $\mathrm{t} / \mathrm{ha}$ ) than the application of nitrogen (ammonium nitrate) or nitrogen-phosphorus fertilizers (FertiM N9P14S10). An increase in the content of crude protein in grain from 9.1 to $10.9 \%$ was noted with the addition of FertiM N10P10K10S9. The yield of spring rapeseed with FertiM application increased by $0.2-0.3 \mathrm{t} /$ ha. The use of FertiM significantly increased the content of crude protein in rapeseed, and tendencies of an increase in crude fat and total phosphorus were noted. The results were obtained on the effect of complex-mixed fertilizers FertiM on soil fertility indicators. The application of complex-mixed fertilizers FertiM increased the content of mineral nitrogen in the soil by 1,1-1,3 times. No deterioration in the indicators of the soil-absorbing complex was observed.

Keywords: mineral fertilizers, spring wheat, spring oilseed rape, productivity, product quality, sod-podzolic soil agrochemical properties of the soil.

\section{Сведения об авторах}

Васбиева Марина Тагирьяновна, кандидат биологических наук, доцент, старший научный сотрудник лаборатории прецизионных технологий в сельском хозяйстве, Пермский научноисследовательский институт сельского хозяйства - филиал Пермского федерального исследовательского центра УрО РАН («Пермский НИИСХ УрО РАН»), 614532, Пермский край, Пермский район, с. Лобаново, ул. Культуры, 12; e-mail: vasbieva@mail.ru

Фомин Денис Станиславович, кандидат сельскохозяйственных наук, старший научный сотрудник лаборатории прецизионных технологий в сельском хозяйстве, «Пермский НИИСХ УpO PAH»; e-mail: akvilonag@mail.ru 
Ямалтдинова Венера Рафхатовна, кандидат сельскохозяйственных наук, старший научный сотрудник лаборатории прецизионных технологий в сельском хозяйстве, «Пермский НИИСХ УpO PAH»; e-mail: pniish@rambler.ru

Шишков Данил Глебович, младший научный сотрудник лаборатории прецизионных технологий в сельском хозяйстве, «Пермский НИИСХ УрО РАН»; e-mail: danil.shishkov@gmail.com

Фомин Дмитрий Станиславович, младший научный сотрудник лаборатории прецизионных технологий в сельском хозяйстве, «Пермский НИИСХ УрО РАН»; e-mail: prm.fomin.d@gmail.com

Новикова Татьяна Владиславовна, младший научный сотрудник лаборатории прецизионных технологий в сельском хозяйстве, «Пермский НИИСХ УрО РАН»; e-mail: pniish@rambler.ru

Полякова София Сергеевна, младший научный сотрудник лаборатории прецизионных технологий в сельском хозяйстве, «Пермский НИИСХ УрО РАН»; e-mail: ss.polyakova@yandex.ru 